\title{
Sustainable Housing in Chilean Patagonia: From Greenhouse to Dwelling
}

\author{
Emil Osorio Schmied ${ }^{1}$, Dr Alex Becker ${ }^{2}$, Carolina Sepúlveda ${ }^{3}$, Rocío Zuloaga ${ }^{4}$
}

\begin{abstract}
The complete lack of a sustainable housing market in the cold and rainy context of Valdivia, Southern Chile $\left(39^{\circ} 49^{\prime} \mathrm{S}, 73^{\circ} 14^{\prime} \mathrm{W}\right)$, draws the need to find an affordable solution for the construction of energy-efficient living spaces. A team of architects undertook the challenge, whilst acknowledging other environmental issues such as the use of recycled materials. Based on research, the greenhouse principle was the focus of the design, as it dealt with prevailing weather conditions in a more proper fashion, by maximising daylight and solar gains during the long, cold winter, and also by allowing small-scale farming all year round, amongst other features. The greenhouse was thought to perform more as an in-between space -in terms of temperature and lightning- to all common zones in a house (e.g., a doorway or a living room), rather than applying to each inhabited space, individually. The architects researched on the above qualities to see whether they applied to the new prototype or not. Both potential overheating -in the short warm season- and glare risks were taken into account, by conducting specific environmental assessments (e.g., natural lighting levels) on both physical and virtual models.
\end{abstract}

Keywords: Environmental design, sustainable dwellings, Southern Chile, extreme weather.

\section{Introduction}

Southern Chile -often called Chilean Patagonia- is a vast territory whose upper boundary is at the 39th parallel south, where the River Calle-Calle coincidently becomes the natural borderline (Said 2012, 38) that defines the limits of this large piece of land at the lower tip of South America. Directly south from this river, the city of Valdivia (39 $49^{\prime}$ S, $73^{\circ} 14^{\prime}$ W) stands as the northernmost inhabited place within the whole region, and it is known for both its rainforest and wetlands, as well as farming traditions left from German immigration from the XIX century. Valdivia city registers an average temperature of only $7.9^{\circ} \mathrm{C}$ during the coldest months and does not rise more than $17^{\circ} \mathrm{C}$ during summer (Sarmiento 2007, 115). It is also important to highlight that recorded rainfall in Valdivia is $1,870 \mathrm{~mm}$ for a normal year (Dirección Meteorológica de Chile 2014). The current housing market in this city is specifically centred on houses designed for the needs of a middle-class family of four to five people. Average units of around $62 \mathrm{~m} 2$ are distributed in either one or two levels, at an equivalent price of USD 71,240 (sourced from several local developers). Nevertheless, taking into account figures such as the usable floor area, number of bedrooms and number of inhabitants per $\mathrm{m} 2$, Valdivia is ranked amongst cities with the lowest housing standards, as stated in an updated report of urban quality of life in Chile (Orellana 2014, 13). Regarding the relationship between interior comfort levels and home energy use, in southern Chile, there are two diverging issues to be addressed (Hempel 2013, 14). These issues are poor environmental performance and high energy consumption, especially for heating purposes.

${ }^{1}$ Architect PUC, Chile; MArch Environmental Design U. of Nottingham, UK. Lecturer at Universidad Austral de Chile.

2 Architect U. Central, Chile; PhD UPC, Spain. He is a lecturer at Universidad Austral de Chile.

${ }^{3}$ Architect U. Austral, Chile; MArch Environmental Design U. of Nottingham, UK. She is a lecturer at Universidad Austral de Chile.

${ }^{4}$ Architect U. Austral, Chile. She is a freelance professional and is also keen on environmental design. 
Although this could be seen as a direct consequence of simply applying current building codes -in terms of thermal behaviour-, the above relationship should nevertheless be vice-versa, so that achieving better interior comfort uses less energy. This type of environmental performance appears to be tougher to reach given the weather conditions in the south of the country, which include long seasons of heavy rainfall, strong winds, and low temperatures. However, current envelope design and insulation in houses does not seem to acknowledge the above conditions by simply following local energy codes. Table 1 below shows how maximum thermal transmittance (MART 2006, 9) allowed for building elements in houses at this location is comparatively higher particularly on walls- than in other regulations abroad, like the ones for UK cities (Part L1A 2013, 15), for instance, under either similar or even milder climate conditions.

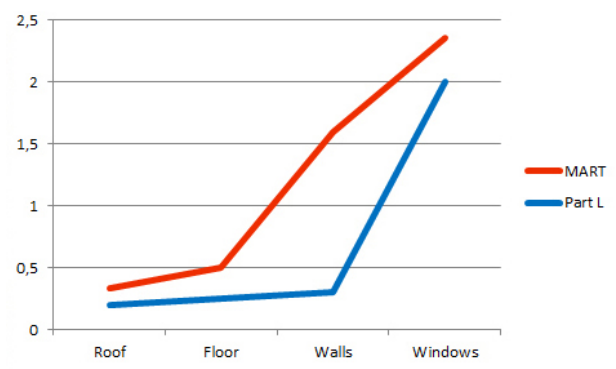

Figure 1: Compared U-values, $W / m 2 K$.

Source: the author 2014.

Having the above differences in mind, a team of architects started the search for an appropriate design for a house that could achieve higher comfort levels under a low-energy consumption scheme, all with the aim of releasing a precedent to be adopted by both public and private sectors at a local level. Hence, the effort was initially put on looking at case studies that seemed to best address the relationship between comfort and energy, and then somehow adapting them to the specific requirements of a single-family dwelling in southern Chile, turning the above into a prototype that could be actually inhabited. The house also serves as a teaching tool, being visited by both groups of interest and general public, as an example of what a sustainable home could be in the context of Valdivia and its surroundings. Relevant feedback on the state of the art had already been received from local organizations, manufacturers and suppliers who were keen in putting into practice the outcomes of this project.

\section{Framework}

"Often underused in mainstream building, passive technologies are design based and virtually free, making them a low-cost, efficient way to condition interior space through simple physical principles." (Chan 2008)

The task for the project team was to find good examples of dwelling design for the local context. Architectural precedents from around the world were examined with this goal in mind. Secondly, from these designs, it was determined, which features (e.g., form, orientation, materials, etc.) were likely to apply to a new house prototype in southern Chile. The aim of reaching a higher comfort level at lower energy consumption, led the search towards the architectural concept of passive design. When addressing passive design from an environmental point of view, McMullan (2012, 353) defines it as the effort on collecting solar energy in buildings. The case the author describes is a glass conservatory attached to a house in the UK, where heat is stored by thermal properties of both the walls and floors. A glass conservatory actually responds to the principle of greenhouse 
effect, where radiation from the sun passes through the glass and then is re-radiated as heat by objects or surfaces inside. Furthermore, in research about these type of attached sunspaces in Chile, engineer Jean-Michel Mottard $(2007,315)$ stated that solar absorption and convective heat on walls directly feed the energy supplied to adjacent rooms up to $11 \%$ during the coldest month (July). Another example of an attached glass conservatory, like one located in Cologne, Germany $\left(50^{\circ} 57^{\prime} \mathrm{N}, 6^{\circ} 58^{\prime} \mathrm{E}\right)$ by architect Robert Laur as seen below in Figure 2, shows that this design not only provides solar energy, but also light and spaciousness. Architect Simone Schleifer $(2007,128-$ 133) acknowledges further advantages of passive design on interior comfort levels, in a compilation of Eco-houses worldwide.

Figure 2: Wintergartenhaus, Germany.

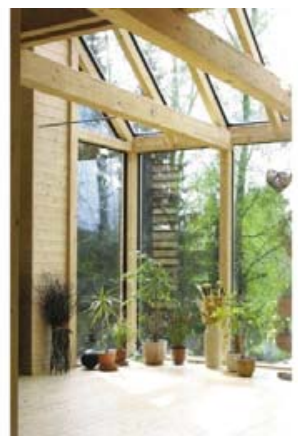

Source: CTaschen 2007.

Yet that feeling of spaciousness and sunny interior spot is not simply achieved by the addition of a glazed volume on just any side of a given dwelling. An optimum façade orientation must be also considered in order to maximise solar gains during the day in colder seasons. For the southern hemisphere, such gains belong mostly to north facing façades. Sarmiento $(2007,257)$ states that these solar building strategies naturally match the concept of passive design and also claims that such strategies must be more than an added feature, but should be considered part of the architectural form. An example of this concept is presented below in Figure 3 by Jestico + Whiles Architects in Cardiff, Wales (51 $29^{\prime} \mathrm{N}, 3^{\circ} 11^{\prime} \mathrm{W}$ ), where a glass conservatory became one with the building structure (southern facing roof and wall). In this case, the flooring is black stone tiles which aid both collecting and storing heat gains via the greenhouse effect. Then, amongst other tasks, the search of a proper on-site orientation in terms of both heat and light gains appeared to be critical, and as the house was to be built in an experimental plot within a semi-rural area beyond the city borders, enough open space to work on the above orientation was likely to be available.

Figure 3: House for the future, $W$ ales. Source: CRockport 2008.

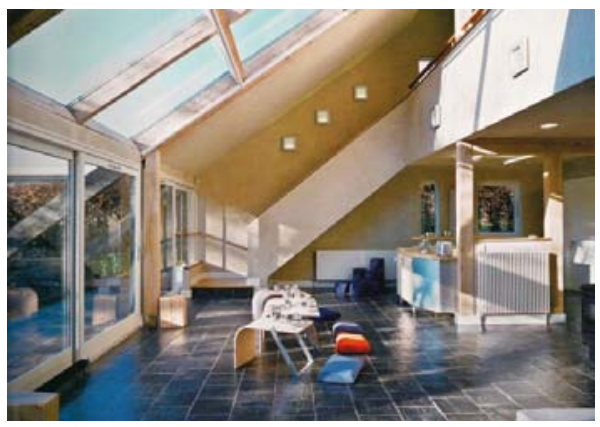

Being located in a semi-rural site may also give buildings the opportunity to make better use of natural ventilation means and even benefit from tree shading in warmer seasons. Architect 
Viviana Guastalla $(2008,84)$ exemplifies this by highlighting the case of the Kurimoto Millennium City project in Tokyo, Japan $\left(35^{\circ} 41^{\prime} \mathrm{N}, 139^{\circ} 41^{\prime} \mathrm{E}\right)$, as shown below in Figure 4 from a publication about ecological houses. Again, the feeling of spaciousness seems to be an added value for dwellings in dense urban areas.

Kurimoto houses seem to take the greenhouse principle to an extreme, as it creates an in-between space through the addition of a separated second skin in front of the interior façades. The inbetween space concept particularly refers to the inhabited transition from one environment to another (Osorio Schmied 2012, 11).

Figure 4: Kurimoto Millennium City, Japan. Source: CteNeues 2008.

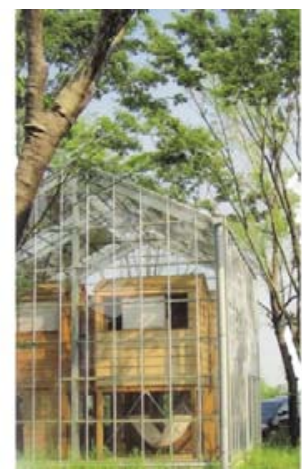

Although the case study revision was conducted in order to find relevant features regarding climate, materials or form, amongst other topics, an approach to the greenhouse principle was first addressed by the winning entry of a competition amongst architecture students, specifically organised with the goal of engaging them with sustainability. The hypothesis is that such principles can be the basis for a house project, but can also serve as the framework for addressing passive design strategies. Then, the design team worked on developing both physical and virtual models in order to try different design-based features that could best meet passive technology principles as those stated by architect Yenna Chan $(2008,57)$ in research about sustainable housing. The ultimate objective was to achieve a more attractive product for an average middleclass family in terms of purchasing, and operating costs.

\section{Design and Construction Process}

It was possible to split the design and construction process into five key milestones prior to completion, starting from the initial greenhouse scheme and finishing with the dwelling project itself. Each of these milestones is linked to relevant decisions, which were based on criteria such as environmental efficiency, use, measurements, or spatial quality, but also based on practical issues that needed to be solved throughout the project development. First was the design concept, then adaptation to a house scheme. An evaluation of some environmental strategies followed, together with the definition of both in-between spaces and the building fabric.

\subsection{The greenhouse scheme}

A call for a design competition amongst architecture students at a local university was made by the project team, with the aim to promote innovation in housing, energy, recycling and design (standing with the acronym VER $+\mathrm{D}$, or "verde" meaning "green" in Spanish).

The architectural brief regarded two bedrooms, a bathroom, a kitchen, and a living room. Another important guideline was to make room for in-between spaces (e.g., corridors, light yards, clerestories, etc.), with the idea of interacting with the outside environment. Figure 5 below 
shows the winning entry, named Casa invernadero 23 ("Greenhouse dwelling 23" in Spanish), which proposed a synthesis of the southern Chilean lifestyle, in the shape of both a double skin greenhouse and a domestic-scaled indoor farm. This design linked the surrounding landscape with the inside under the protection of a symmetrical double-pitched glazing.

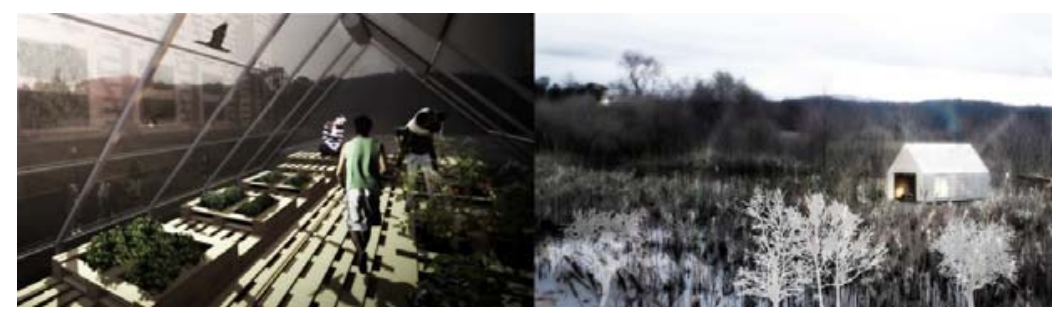

Figure 5: Casa Invernadero 23, Valdivia. General views.

Source: the author 2014.

The proposal fitted the bed, bath, kitchen and living rooms in a compact wooden box of approximately $60 \mathrm{~m} 3$ placed slightly above ground level. Both its floor and shorter walls were directly exposed to the external environment whilst other surfaces remained within the greater greenhouse space $(150 \mathrm{~m} 3)$, as seen in Figure 6 below. A dedicated farming deck was left on the first floor in order to secure a year-round micro production of vegetables (e.g., tomatoes, green leafs, etc.), given direct solar gains from the fully-glazed roof, especially during winter. The challenge at this point was making sure that such productive use would actually transfer to a dwelling scheme. When addressing greenhouse design for farming purposes, engineer Bram Vanthoor $(2012,351)$ reveals some elements that architects may carefully consider when thinking of sunspaces in a building project: structure, covering materials, potential outdoor shading and cooling strategies. Hence, an early revision on the relationship between glazing and opaque surfaces was useful to see whether this relationship could determine heat gain and energy conservation in the long cold season or not. In this proposed scheme, glazing covered most of the $134 \mathrm{~m} 2$ of all vertical and pitched surfaces, whilst solid areas are a very small portion of it (ratio of 9:1), so U-value in walls, for instance, seems to be considerably higher than the one expected for that building element in houses as seen previously in a comparative chart.
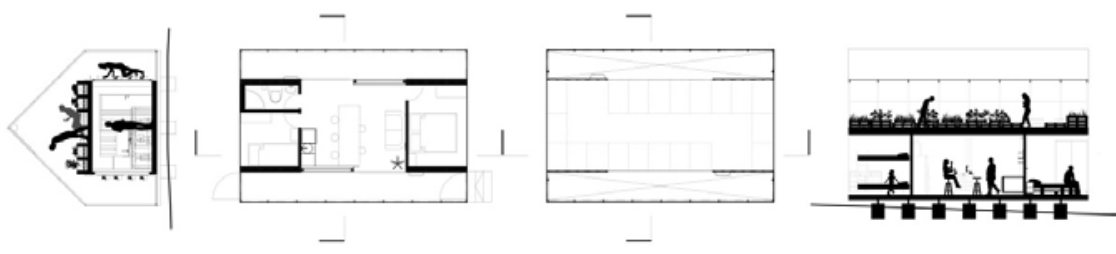

Figure 6: Casa Invernadero 23, V aldivia. Plans and sections.

Source: the author 2014.

\subsection{Becoming an inhabited space}

To turn the above proposal into a proper dwelling, one of the first tasks was to adjust the entire greenhouse space in a $6.7 \mathrm{~m}$ by $11.2 \mathrm{~m}$ rectangular plan that actually suited the gross area on ground floor as requested in the VER $+\mathrm{D}$ house competition rules. It was important to compare the above size with the $62 \mathrm{~m} 2$ average unit that is available in the local housing market for middle-class families. Figure 7 below shows some of the approaches for using the greenhouse principle in a house project, where the differences mostly lay in the amount of glazing and its 
distribution on external façades. In addition to the concept of a dwelling as a fully-exposed space in terms of daylighting and views, there is also an opportunity to use glass as the envelope to a solid box where individual rooms may be contained, leaving all common zones in an in-between condition in terms of lighting and temperature, similar to the Kurimoto case study. Another design has an attached sunspace on one side (glazing/solid ratio of 1:4), in order to maximise solar orientation as a glass conservatory would do, just like in the Wintergartenhaus project. Finally, integrating a greenhouse into the building structure (glazing/solid ratio of 1:12) appears to be a practical solution when thinking of a home as a continuous form, as seen in the House of the future precedent.
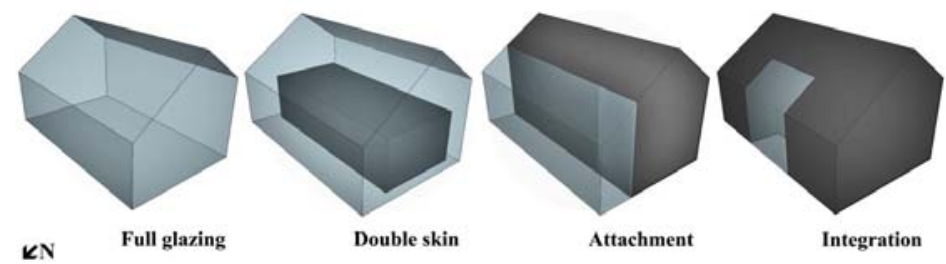

Figure 7: Potential adaptations of a greenhouse space.

Source: the author 2014.

The adaptation process implied that one of the two side corridors, specifically the one facing south, had to be removed as no natural heat gains would be obtained on such side, given the optimum solar orientation in the southern hemisphere. Hence, the northern corridor was kept in place so that the greenhouse effect could be naturally maximised. However, the above effect had to be complemented with the addition of opaque surfaces, given the need for increasing energy conservation during the long cold season. Potential insulation was regarded as a distinctive feature if building elements were to be compared to typical greenhouse fabric. A long horizontal window was added to the opaque south façade with the only aim of preserving the view. Also, a staircase was placed on one of the narrowest sides in order to connect with the farming deck on the first floor (Figure 8). Two access doors were placed at each corridor end, on both the east and west façades. The rooms remained practically the same as the initial layout, with a usable height of $2.35 \mathrm{~m}$, whilst the whole building reached $7 \mathrm{~m}$ high, measured from the natural ground level.
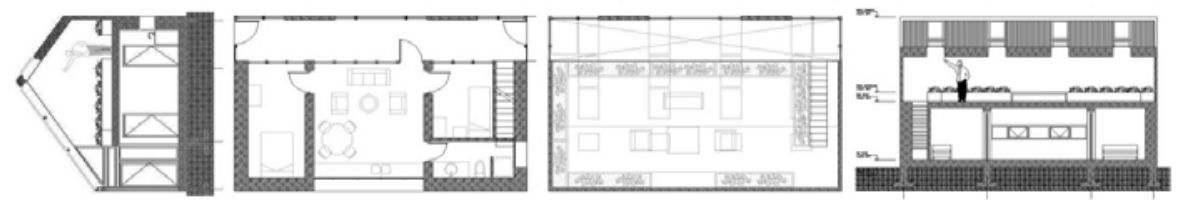

Figure 8: VER $+D$ house prototype. Plans and sections.

Source: the author 2014.

\subsection{Lighting and ventilating}

The roof was partly glazed, partly opaque -mainly the north side- so that overheating via solar gains would be avoided. Then four openings -in the shape of vertical stripes- were proposed on the same side in order to let the sun in and to let exhaust air out of the building. Other smaller openings were placed on the south pitch with the objective of generating cross ventilation. As a principle, this strategy looked to reduce the amount of glazing on the north roof -formerly fully glazed- where high-angle direct sunlight falls during various weeks in summer. Figure 9 shows the results of combining both an attached and integrated sunspace on the north façade as in the 
VER+D house, and then turning some of its translucent sloped panes into opaque surfaces (yet the glazing/solid ratio is 1:4). The latter was done so that potential need for solar shading in further design stages was addressed. Windows along the roof were subject to a last revision in order to meet the desired approach to both solar control and gains. Openings on the roof top were put close to one another and near the ridge, so that cross ventilation could easily work at the above level without the assistance of any active system, given the buoyancy effect of the exhaust air inside. It is important to highlight that all windows were outlined as double-glazed units, following local regulations.
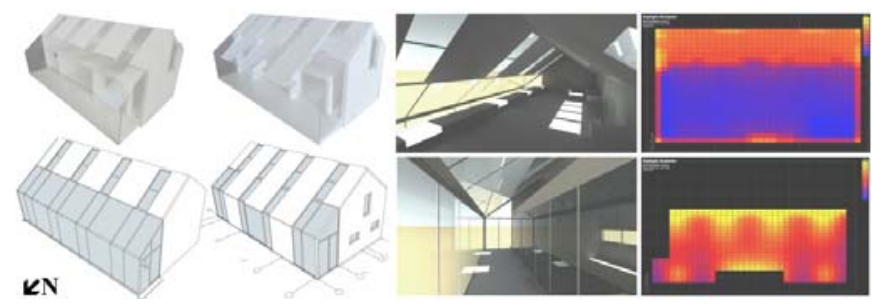

Figure 9: Design process. Daylight analysis.

Source: the author 2014.

\subsection{The in-between condition}

Regarding daylighting in buildings, McNicholl $(1994,9)$ stated that a clear glass pane can let around $85 \%$ of daylight in. The idea of developing the proposal from a glass volume was to relate the house to its surrounding context through the use of in-between spaces. Then the different house functions were split into specific zones according to rates of sun exposure. For instance, the two bedrooms were located in the most protected areas (coloured blue in Figure 9), as if they were contained in a box within another (glass) box, whilst the air gap between them becomes an inhabited in-between space (orange/yellow).

As seen in the natural lighting simulation, zones covered by glazing benefited from far above 5\% of direct daylight. Moreover, such percentage is the maximum recommended for interior spaces, according to dedicated authors like architect Dereck Phillips (2004, 8) when stating the effectiveness of combining windows on façades. Therefore, in terms of natural lighting, it is possible to label zones such as the corridor or the first floor terrace as in-between spaces, defined before as the transition from one environment to another. Nevertheless, and despite direct solar gains, inside temperature for the above spaces is expected to be around $15^{\circ} \mathrm{C}$, which is less than what is expected for the bedroom area. Further on-site monitoring should confirm this assumption.

\subsection{Building envelope and insulation}

The size of building elements was influenced by the potential combination of different construction techniques. For example, foundation depth and the ground slab was determined by the extensive use of recycled PET bottles (empty and airtight) as filling material. These were stood attached to each other and covered with natural soil. The reuse of other waste materials, such as plastic coated paper carton (e.g., TetraPak boxes) for insulating purposes, was considered in the ceiling. Also, straw bales were utilized to insulate all perimeter walls, which in turn were prefabricated timber structures that could contain the bales. Figure 10 shows that both PET bottles and straw bales are part of a continuous thermal envelope in which $\mathrm{U}$-values range between $0.08 \mathrm{~W} / \mathrm{m} 2 \mathrm{~K}$ for the floor and $0.18 \mathrm{~W} / \mathrm{m} 2 \mathrm{~K}$ for walls. At roof level, a double layer of empty and re-shaped TetraPak boxes obtains a thermal transmittance of $0.26 \mathrm{~W} / \mathrm{m} 2 \mathrm{~K}$. 
Corrugated zinc panels have been outlined for cladding opaque surfaces to all external walls and the roof as well.
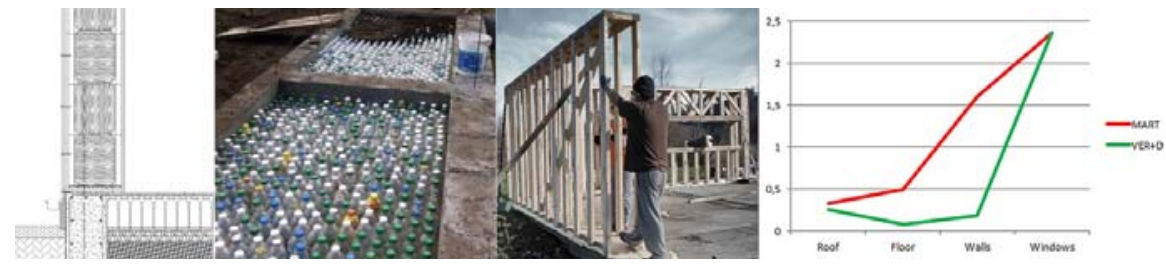

Figure 10: Building fabric. Floor, walls, U-values.

Source: the author 2014.

\section{Conclusions}

The opportunity to stare at the surrounding rainforest landscape whilst it is heavily raining, or the chance to grow vegetables at home when it is very cold outside, are amongst the added values of the VER+D prototype. This is why the greenhouse principle was specifically picked for shaping the design of a dwelling in the extreme context of southern Chile. Some design assumptions, such as the glazing/solid ratio, the in-between zone, or the building insulation, have been already put into practice during the construction stage, and deal with questions raised from the adaptation from a greenhouse scheme to an inhabited space. It was possible to learn different approaches to glass sunspace design from the case study stage, which were all finally combined in a single structure, in an effort to transfer the greenhouse principle into a new design project, through the use of passive strategies, especially to maximise daylight during winter. Options such as a double-skin, an attached or integrated greenhouse -all of which are north-facing elements- are converted into a single space in the dwelling prototype. Glazing/solid ratios were strictly kept at $1: 4$, but sequentially distributed along the building façade in the form of stripped vertical windows that also help the house to avoid potential overheating during some weeks in summer. This distribution also follows a simple ventilation principle, which consists in making windows able to open on both sides near the ridge in order to extract warm air masses at a higher level, whilst fresh air gets in through openings on the ground floor. The hypothesis was that an in-between zone could contain all common areas of the house, such as a circulation space, for instance. This meant that these areas would function with both different temperature and daylighting levels, compared to the bedroom zone. Lighting simulations showed that natural light gains were far above $5 \%$ of the external light, which superseded what was expected for an interior space. On the other hand, design temperature for in-between spaces was set on $15^{\circ} \mathrm{C}$ in order to create an inhabited and tempered buffer zone between bedrooms and the outside. Post-occupancy monitoring is to confirm if the above works as expected, however, the potential addition of active heating systems is not yet considered. Finally, insulation is perhaps one of the most distinctive features in which the VER $+\mathrm{D}$ prototype can contribute to the existing housing realm in southern Chile. Insulation -unknown in terms of typical greenhouse construction- is mainly placed in south facing walls, where no solar gains and only heat losses can be expected. Moreover, the use of recycled materials on floors and ceilings, such as either PET bottles or plastic coated paper carton, grants the achievement of lower thermal transmittance levels and lower construction budgets as well. The addition of straw bales to walls has secure high insulating properties if well protected against rain, for instance. The above innovation is what may allow the private zones of the house to work simultaneously with the farming function on the first floor terrace, making the most of the greenhouse principle in both environments, as shown below in Figure 11. Although there are recent requests from rural communities to adopt the VER+D typology in some new 
housing developments, the next challenge is to put its design principles to test in a fully urbanised condition, and see how it works in terms of interior comfort and energy performance.

\section{References}

Chan, Y. (2007). Sustainable environments. Gloucester, Mass.: Rockport.

Guastalla, V. (2008). Ecological houses. Kempen, Germany: TeNeues.

Hempel, R. et al. (2013). El estándar Passivhaus en Chile. Concepción, Chile: Universidad del Bío-Bío.

Dirección Meteorológica de Chile. (n.d.). Retrieved February 28, 2015, from http://www.meteochile.gob.cl/inf precipitacion.php

McMullan, R. (2012). Environmental science in building (7th ed.). Basingstoke, England: Macmillan.

McNicholl, A. and J. Owen Lewis, eds. (1994). Daylight in Buildings. Dublin, Ireland: European Commission.

Ministerio de Vivienda y Urbanismo - Gobierno de Chile - (Mi Vivienda). (n.d.). Retrieved November 15, 2014, from http://www.minvu.cl/opensite 20070402125030.aspx

Mottard, J.M. and A. Fissore (2007). "Thermal simulation of an attached sunspace and its experimental validation". Solar Energy 81: 305-315

Orellana, A. (2014). ICVU Indicador de calidad de vida ciudades Chilenas. Santiago, Chile: Instituto de Estudios Urbanos y Territoriales PUC.

Osorio Schmied, E. (2012). In-between spaces in Antofagasta. Relationship of architecture with its context. AUS 12: 10-13

Phillips, D. (2004). Daylighting natural light in architecture. Amsterdam: Elsevier.

Said, J. (2012). Patagonia. (1st English ed.). Santiago, Chile: Patagonia Media.

Sarmiento, P. (2007). Energía solar en arquitectura y construcción. Santiago, Chile: RIL Editores.

Schleifer, S. (2007). Small eco-houses = Petites maisons écologiques = Kleine Ơkohäuser. Köln: Evergreen.

The Building Regulations. "L1A Conservation of fuel and power in new dwellings." (n.d.). Retrieved December 22, 2014, from https://www.planningportal.gov.uk/uploads/br/BR PDF AD L1A 2013.pdf

Vanthoor, B. et al. (2012). "A methodology for model-based greenhouse design: Part 5". Biosystems Engineering III: $350-368$ 
